\title{
IMPACT OF MACHINING ON THE ENVIRONMENT
}

\author{
Tetjana Tomaskova \& Katerina Bicova
}
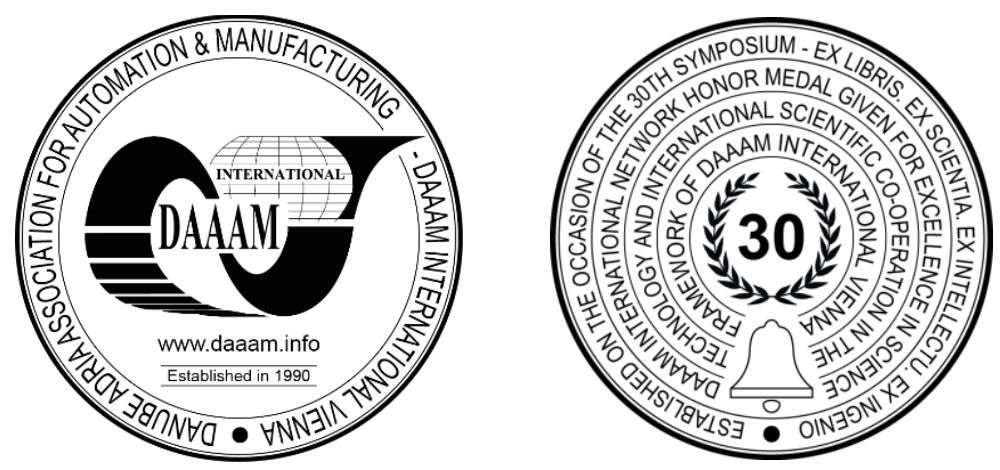

This Publication has to be referred as: Tomaskova, T[etjana] \& Bicova, K[aterina] (2021). Impact of Machining on the Environment, Proceedings of the 32nd DAAAM International Symposium, pp.0623-0630, B. Katalinic (Ed.), Published by DAAAM International, ISBN 978-3-902734-33-4, ISSN 1726-9679, Vienna, Austria

DOI: $10.2507 / 32$ nd.daaam.proceedings.088

\begin{abstract}
Since about the middle of the last century, the state of the environment has been deteriorating and, in connection with this, the pressure to protect the environment has begun to increase, so industrial companies must comply with environmental legislation. Industrial companies' implementation of the environmental management system on a voluntary basis and by implementing them undertake to carry out all their activities in an environmentally friendly manner. This trend affects not only social but also economic development and, last but not least, the satisfaction and health of the population. Sustainable development makes it possible to meet the current needs of the human population without compromising the living standards of future generations and preserving the planet's ecosystem. The article describes the issue of the impact of the metalworking industry, specifically machining, on the environment. The authors aim to design a register of environmental aspects identified in machining according to ISO 14001. This register of environmental aspects will serve as a basis for the subsequent processing of the required documentation for the certification of the company according to ISO 14001.
\end{abstract}

Keywords: Environment; environmental aspects; sustainable development; metalworking industry; machining;

\section{Introduction}

Society has changed over the years and with it the view of certain problems that previous generations did not perceive as problems that need to be addressed. If we talk about the natural environment, then man was an integral part of human evolution at the beginning. Among the reasons for this was, first and foremost, the effort to stay alive, which was later replaced by the fulfilment of human needs, which, however, resulted in man's disruption of the environment in connection with the scientific and technological revolution and industrial development. Under all the above (i.e. the natural environment, the scientific and technological revolution, industrial development and socio-economic conditions), it is possible to imagine an intertwined system, which is referred to as the environment [1], [2], [3], [4].

According to the ISO 14001 standard, the environment is defined as the environment of a company, including air, water, soil, natural resources, plants, animals, people and the relationships between them. Because of this, the environment cannot be referred to as a business problem, but it must be referred to as a global system problem. The aim of this research is to focus on the impact of the metalworking industry, specifically machining, on the environment in general, and to try to design a general register of environmental aspects according to the requirements of ISO 14001, which can be identified in machining. The aim is to prepare a basis for the subsequent processing of the required documentation for the certification of the company according to ISO 14001. 


\subsection{Machining and environment}

The environment is an issue that does not only concern the corporate sphere, but it is a global sphere. The same is true of the machining environment. The machining process itself includes the energy and resource flows that are necessary for a given production. Other aspects influencing the environmental impact of the machining process include the factory itself or the company's building with a heating, ventilation and air conditioning system, and even the supply chain (see Fig. 1) [5].

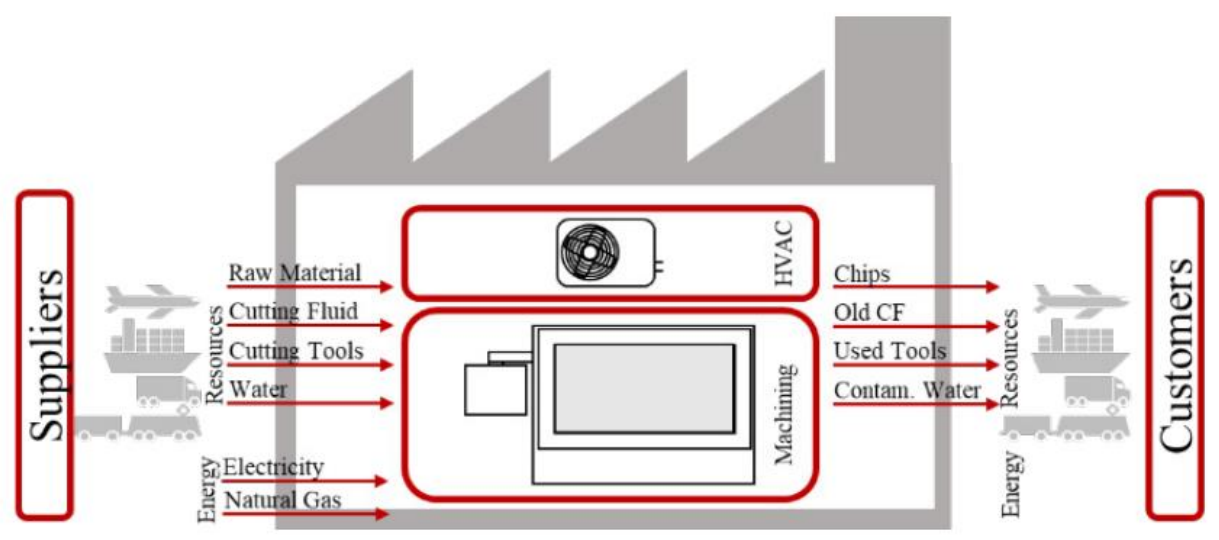

Fig. 1. Energy and Resource Flows [5]

The place where the factory is located is very important here. From a global perspective, there is a different flow of energy and resources when assessing the environmental impact of a company located in Germany or the Czech Republic and a different flow when assessing a company located in India. Especially in terms of key factors: supply chain, climate, available energy carriers, disposal and recycling (see Fig. 2) [5].

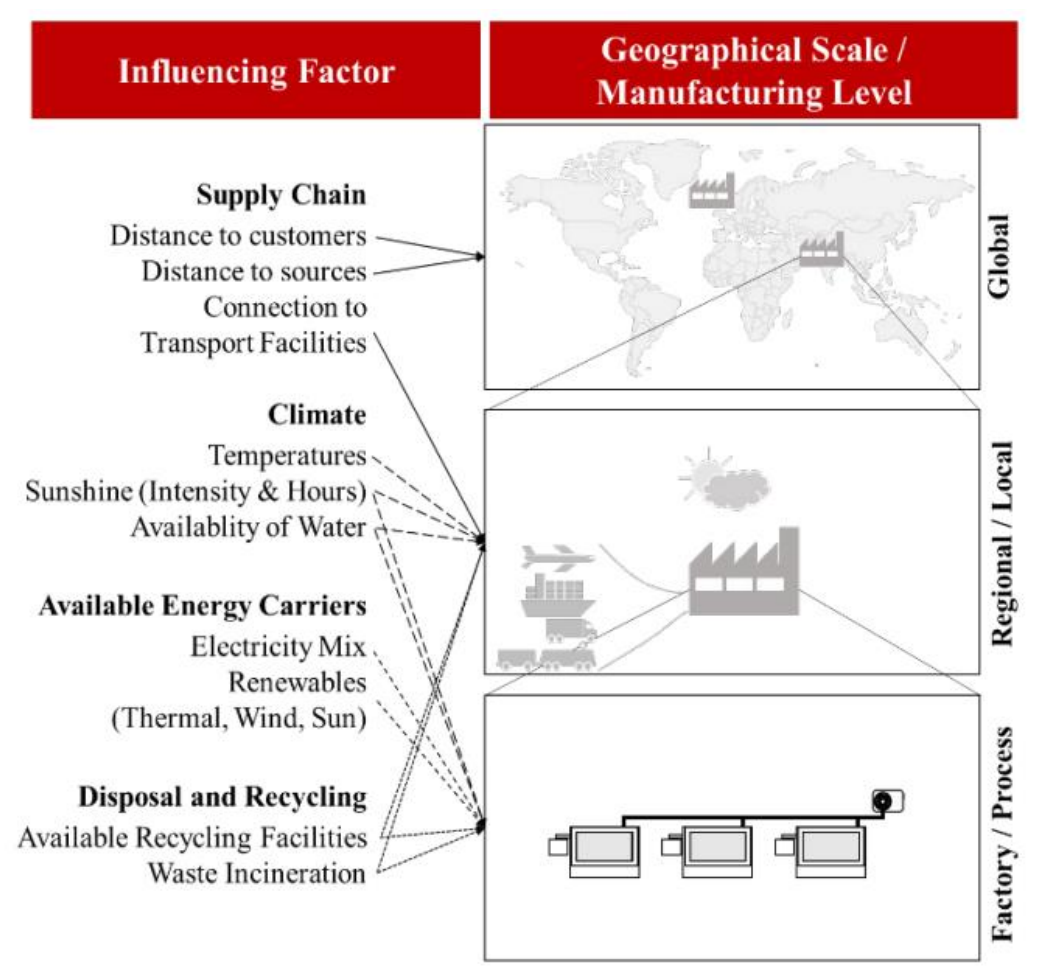

Fig. 2. Factors influencing the sustainability of a machining process [5]

The first of these is the supply chain, which includes mainly the distance of the factory from suppliers and customers, but also the mode of transport. Each country has a different infrastructure, and the possibility of using a certain transport may be one of the options where the company can reduce the burden on the environment. In addition to the availability of transport, this also includes the distance of the service, warehouse and auxiliary resources (e.g. cutting fluids, tools). 
The second factor is the climate of the area where the company is located. Climatic conditions affect the energy required for the HVAC system (Heating, ventilation and air conditioning) and for machine tools. The main problem is businesses that are located in areas with extreme climatic conditions, because intensive heating or cooling is required there, which leaves an ecological footprint behind. The availability of water resources is also important here, as an important source for material processing and cooling during machining processes. The third important factor influencing the impact on the environment during the machining process is the type of energy mix available in the company. CNC machining consumes electricity in various operations and, as a result of this production, generates emissions that depend on the location of the company, the resources used and the technology used. The last key factor is the distance of sales and recycling equipment from the place of business, including recycling itself and the used recycling technology. In general, however, environmental policy strictly promotes the availability of high - level recycling and disposal facilities $[5],[6],[7]$.

\section{Impact of industry on the environment}

\subsection{Impact of the metalworking industry on the environment}

The company, which deals with metal processing, follows the scheme of the production process. This means that there are certain inputs that will be converted into certain outputs by a given production process. The environment also influences the whole production process. Figure 3 shows that the inputs include mainly input materials, consumables, semi-finished products, but also energy. It is also shown that among the outputs we have products, residual materials, but from an environmental point of view mainly emissions, polluted materials, polluted wastewater or polluted air. These are the environmental burdens that companies interested in the environment try to minimize. [8], [9].

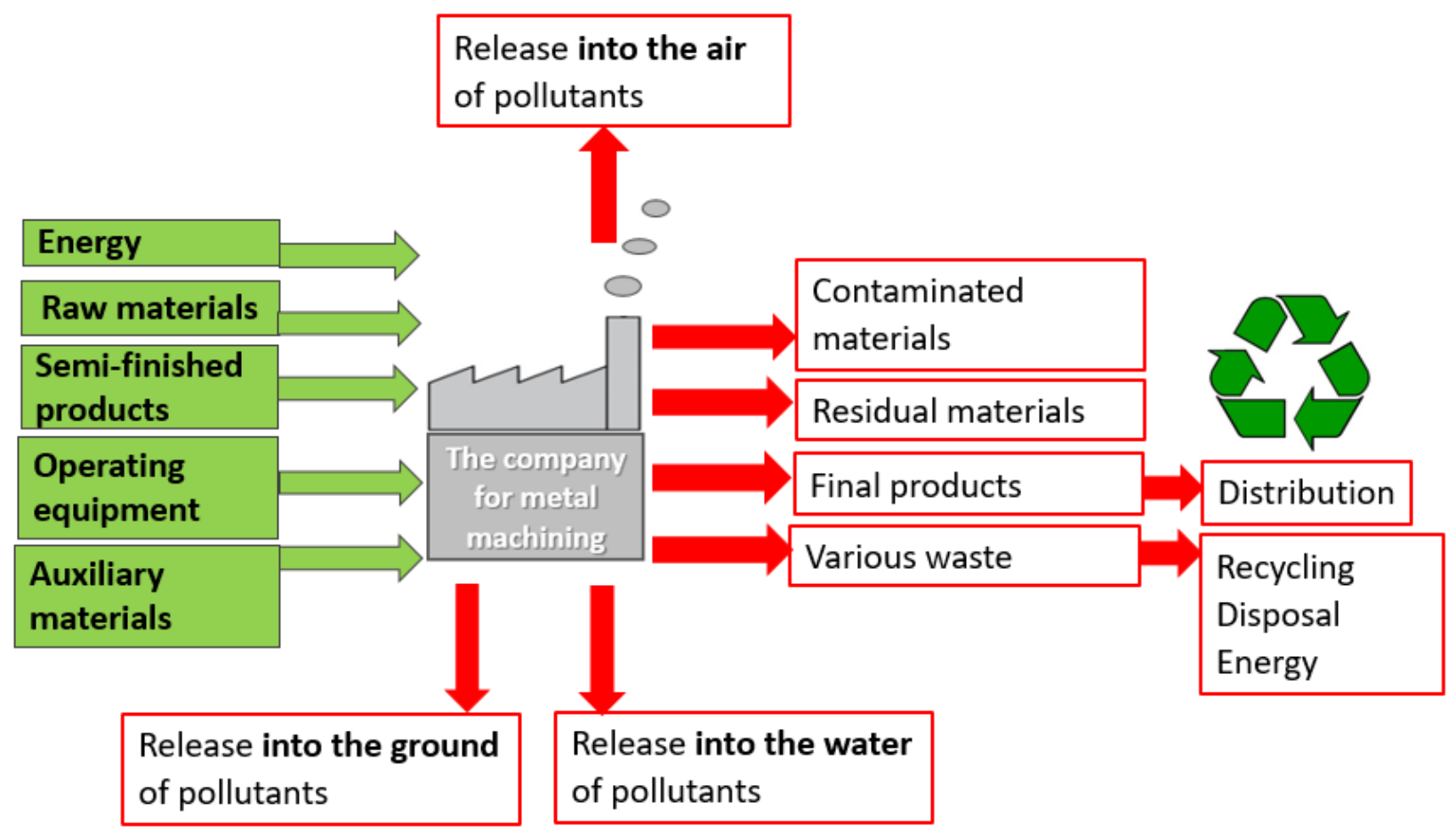

Fig. 3. Inputs and outputs of an industrial company for metal machining

\subsection{Impact of machining on the environment}

To determine the correct impact of machining on the environment, it is first necessary to realize what the production process of machining looks like and what it is affected from the point of view of the environment (see Fig. 4). An example can be the actual transport of material to the company or the actual extraction of this material. The energy consumed, which is needed for proper operation, also has a certain impact, but the outputs that are created together with the product are a bigger problem. The first of these outputs is chips. If chips are treated badly, they have a certain impact on the environment. In most cases, these chips are recycled and further processed, so that the impact is minimized. The second output is coolants and lubricants, which are the real problem. This can be a substance with a long disintegration time or a cancer-causing substance. At the same time, these products can pollute wastewater if used incorrectly, which can have irreversible consequences for the environment. If it is possible to use water-based products, it is important to use them, because chemical waste is dangerous from the waste generated during production. 


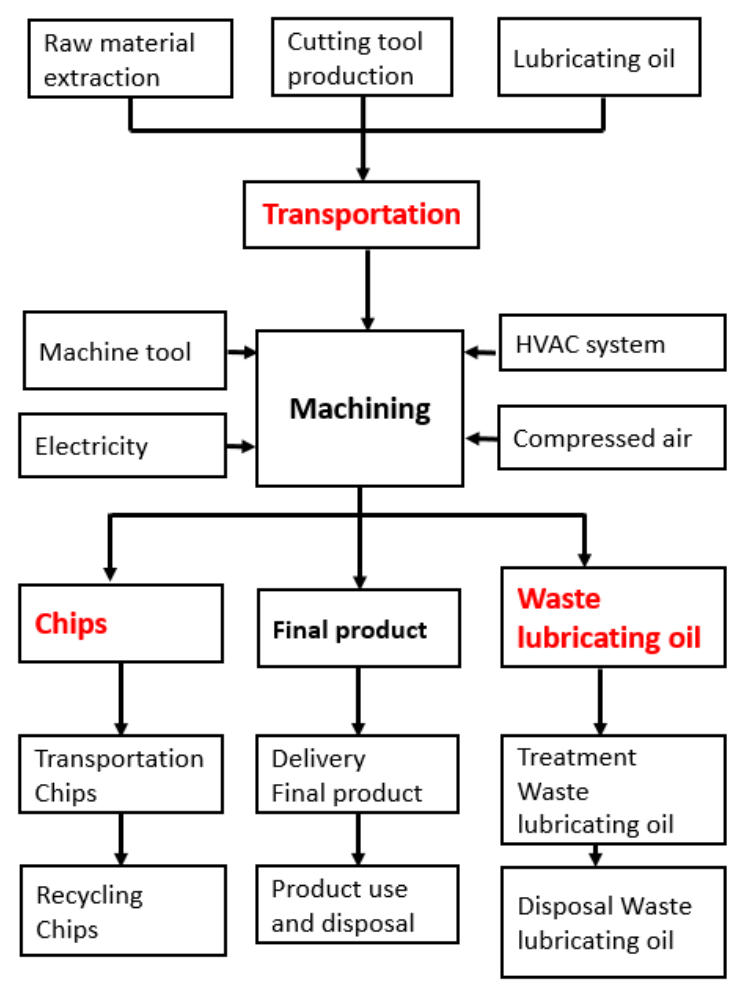

Fig. 4. Machining process

Emissions can be another impact on the environment during machining. An example of the cause of air pollution is dust. Here it depends mainly on the type of material that is ground. E.g. when grinding aluminum materials, dust is released into the work area, which can form an explosive atmosphere with the air. In this case, it is necessary to extract dust directly during the grinding process, and the most efficient way is to extract abrasive aluminum dust directly at the source. By summarizing everything that has been said, it can be stated that it is necessary to evaluate all the environmental impact of machining. Furthermore, it is necessary to know the exact production process of a particular product, because even the environmental impacts may differ from product to product, for example, because other production methods or other means of operation can be used.

\section{Preparation of a register of environmental aspects}

ISO 14001 requires an organization to establish and follow a procedure to identify the environmental aspects of its activities, services and products. The result is aspects that the organization can directly manage or have some influence on, but the most important thing is to identify those aspects that have or may have a significant impact on the environment. According to the standard, it is necessary to map all aspects of activities by which the company affects the environment. However, the standard does not specify the exact procedure for carrying out this analysis, as it is assumed that this procedure will be proposed by the organization itself. However, the condition remains that the subject of interest will be all activities, products and services that are the subject of the organization's activities or over which the organization has an influence.

The company for which we are preparing environmental aspects consists only of a production hall and a warehouse for storage of inputs and outputs. Therefore, the administration, the vehicle fleet will not be taken into account, but also the dining room, which usually does not occur in the same way in similarly small companies. Nor will it be assumed that the company shares the place with other organizations (ie the company is considered as a separate entity). To facilitate the listing of individual negative effects on the environment, the following typical groups are listed:

- Use of hazardous chemicals and preparations

- Waste production (with emphasis on hazardous waste)

- Water pollution (e.g. waste water discharges, leaks)

- Soil contamination

- Emissions to air

- Odor nuisance

- Excessive noise emissions

- Exceeding hygienic limits for the working environment

- Consumption of raw materials and energy

- Impacts on human health and safety. 
Once all the environmental aspects have been mapped, they need to be evaluated and the essential aspects identified. How to carry out this evaluation again is not directly determined by the standard and it is only up to the company itself what criteria and procedures it will choose. The following criteria were chosen for this work.

\section{Frequency of occurrence or duration of the effect:}

- Continuously 5

- Often (daily) 4

- Regularly (monthly) 3

- Rarely (annually) 2

- Almost never 1

\section{Severity of influence:}

- Serious 4

- Significant 3

- Normal 2

- Negligible 1

\section{Possibility of an accident:}

- It must be assumed 5

- Exceptional 4

- Not expected, but has ever happened 3

- Almost impossible 2

- Impossible 1

\section{Costs:}

- Threatening 3

- Significant 2

- Insignificant 1

\section{Activity regulated by legislation:}

- Yes $\quad \mathrm{Y}$

- No N

The criterion "Legislative activity" only indicates whether the environmental aspect is regulated or not. It has no value of significance and is therefore not taken into account in the overall assessment, but in the case of significant aspects that are regulated by law, their significance needs to be taken with greater emphasis.

\section{Rating:}

Frequency $\cdot$ Severity $\cdot$ Accident $\cdot$ Cost $=$ Significance EA

\section{Significance of EA:}

- Common aspect 1-50

- Significant aspect 51-150

- Alarming significant aspect $150-300$

There is no need to implement any corrective measures for common aspects. Significant aspects need to be further addressed and appropriate corrective measures implemented to reduce their relevance. In the case of alarmingly important aspects, immediate action is needed, because they are so serious that ignoring them could have irreversible consequences for the environment. For the proposed register, the impact is related to the group water, soil, air, resources and man. In practice, the evaluation takes place in a working team of people who work together to implement EMS (environmental management system) in the company. 


\begin{tabular}{|c|c|c|c|c|c|c|c|c|c|c|c|c|c|c|}
\hline \multicolumn{15}{|c|}{ Register of environmental aspects } \\
\hline \multicolumn{15}{|c|}{ Machining hall } \\
\hline \multirow{2}{*}{$\begin{array}{l}\text { Proces } \\
\qquad \begin{array}{l}\text { Environmental } \\
\text { aspect }\end{array}\end{array}$} & \multicolumn{5}{|c|}{ Impact } & \multicolumn{6}{|c|}{ Assessment } & \multirow{2}{*}{ 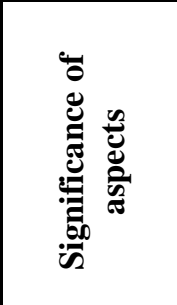 } & \multirow{2}{*}{ 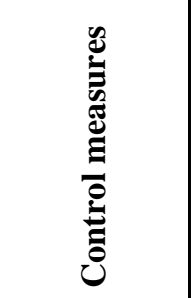 } & \multirow{2}{*}{ 象 } \\
\hline & 离 & $\overline{\overline{\mathscr{D}}}$ & 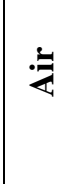 & 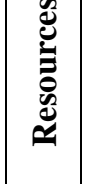 & $\sum_{\Sigma}^{\tilde{\Xi}}$ & 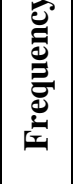 & 承 & 竜 & 品 & 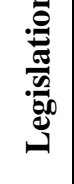 & 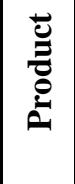 & & & \\
\hline \multicolumn{13}{|c|}{ Storage of waste, hazardous waste and hazardous substances } & & \\
\hline $\begin{array}{l}\text { Generation of } \\
\text { general waste }\end{array}$ & & $\cdot$ & & & $\cdot$ & 4 & 2 & 2 & 1 & A & 16 & Common & Training & $\begin{array}{l}\text { Continuous } \\
\text { monitoring }\end{array}$ \\
\hline $\begin{array}{l}\text { Hazardous waste } \\
\text { generation }\end{array}$ & $\cdot$ & $\cdot$ & $\cdot$ & & - & 3 & 2 & 3 & 1 & A & 18 & Common & Training & $\begin{array}{l}\text { Continuous } \\
\text { monitoring }\end{array}$ \\
\hline $\begin{array}{l}\text { Leakage of } \\
\text { hazardous } \\
\text { substance outside } \\
\text { the designated } \\
\text { containment tank }\end{array}$ & $\cdot$ & $\cdot$ & $\cdot$ & & - & 2 & 4 & 3 & 3 & A & 72 & Significant & $\begin{array}{l}\text { Emergency } \\
\text { plan }\end{array}$ & $\begin{array}{l}\text { Accident } \\
\text { record }\end{array}$ \\
\hline \multicolumn{15}{|c|}{ Use of resources and energy (electricity, water, natural gas) } \\
\hline $\begin{array}{l}\text { Use of non- } \\
\text { renewable } \\
\text { resources }\end{array}$ & & • & & $\cdot$ & - & 5 & 2 & 3 & 1 & $\mathrm{~N}$ & 30 & Common & $\begin{array}{l}\text { Responsible } \\
\text { person }\end{array}$ & $\begin{array}{l}\text { Continuous } \\
\text { monitoring }\end{array}$ \\
\hline $\begin{array}{l}\text { Drinking water } \\
\text { consumption }\end{array}$ & - & & & - & $\bullet$ & 4 & 2 & 2 & 1 & $\mathrm{~N}$ & 16 & Common & $\begin{array}{l}\text { Responsible } \\
\text { person }\end{array}$ & $\begin{array}{l}\text { Continuous } \\
\text { monitoring }\end{array}$ \\
\hline $\begin{array}{l}\text { Domestic water } \\
\text { consumption }\end{array}$ & $\cdot$ & & & - & & 4 & 2 & 2 & 1 & $\mathrm{~N}$ & 16 & Common & $\begin{array}{l}\text { Responsible } \\
\text { person }\end{array}$ & $\begin{array}{l}\text { Continuous } \\
\text { monitoring }\end{array}$ \\
\hline $\begin{array}{l}\text { Natural gas } \\
\text { consumption }\end{array}$ & & $\cdot$ & & $\cdot$ & & 4 & 2 & 2 & 1 & A & 16 & Common & $\begin{array}{l}\text { Responsible } \\
\text { person }\end{array}$ & $\begin{array}{l}\text { Continuous } \\
\text { monitoring }\end{array}$ \\
\hline $\begin{array}{l}\text { Emissions from } \\
\text { natural gas } \\
\text { combustion }\end{array}$ & & & $\cdot$ & & $\bullet$ & 4 & 2 & 2 & 1 & $\mathrm{~N}$ & 16 & Common & $\begin{array}{l}\text { Responsible } \\
\text { person }\end{array}$ & $\begin{array}{l}\text { Continuous } \\
\text { monitoring }\end{array}$ \\
\hline $\begin{array}{l}\text { Oxygen } \\
\text { consumption } \\
\text { during natural gas } \\
\text { combustion } \\
\end{array}$ & & & $\cdot$ & - & - & 4 & 2 & 1 & 1 & $\mathrm{~N}$ & 8 & Common & $\begin{array}{l}\text { Responsible } \\
\text { person }\end{array}$ & $\begin{array}{l}\text { Continuous } \\
\text { monitoring }\end{array}$ \\
\hline \multicolumn{15}{|c|}{ Production process } \\
\hline $\begin{array}{l}\text { Generation of } \\
\text { general waste }\end{array}$ & & $\bullet$ & & & $\bullet$ & 4 & 2 & 2 & 1 & A & 16 & Common & Training & $\begin{array}{l}\text { Continuous } \\
\text { monitoring }\end{array}$ \\
\hline $\begin{array}{l}\text { Hazardous waste } \\
\text { generation }\end{array}$ & $\cdot$ & $\bullet$ & - & & $\bullet$ & 3 & 3 & 3 & 1 & A & 27 & Common & Training & $\begin{array}{l}\text { Continuous } \\
\text { monitoring }\end{array}$ \\
\hline $\begin{array}{l}\text { Consumption of } \\
\text { metallurgical } \\
\text { material }\end{array}$ & & • & & - & & 4 & 2 & 1 & 1 & $\mathrm{~N}$ & 8 & Common & Training & $\begin{array}{l}\text { Production } \\
\text { records }\end{array}$ \\
\hline
\end{tabular}




\begin{tabular}{|c|c|c|c|c|c|c|c|c|c|c|c|c|c|c|}
\hline $\begin{array}{l}\text { Generation of } \\
\text { waste from } \\
\text { metallurgical } \\
\text { material }\end{array}$ & - & $\bullet$ & $\bullet$ & & - & $\mid$ & 3 & 3 & 2 & A & 72 & Significant & Training & $\begin{array}{l}\text { Production } \\
\text { records }\end{array}$ \\
\hline $\begin{array}{l}\text { Use of cutting oil } \\
\text { in machining }\end{array}$ & - & • & $\bullet$ & - & & 4 & 3 & 3 & 2 & A & 72 & Significant & Training & $\begin{array}{l}\text { Production } \\
\text { records }\end{array}$ \\
\hline $\begin{array}{l}\text { Waste oil } \\
\text { formation }\end{array}$ & - & - & • & & - & $\mid 4$ & 3 & 4 & 2 & A & 96 & Significant & Training & $\begin{array}{l}\text { Production } \\
\text { records }\end{array}$ \\
\hline Use of chemicals & & & $\bullet$ & - & - & $\mid 2$ & 3 & 3 & 1 & A & 18 & Common & Training & $\begin{array}{l}\text { Continuous } \\
\text { monitoring }\end{array}$ \\
\hline $\begin{array}{l}\text { Formation of } \\
\text { inconsistent dust } \\
\text { emissions during } \\
\text { grinding }\end{array}$ & & & $\bullet$ & & - & 4 & 3 & 1 & 1 & A & 12 & Common & Training & $\begin{array}{l}\text { Continuous } \\
\text { monitoring }\end{array}$ \\
\hline Noise & - & $\bullet$ & - & & - & $\mid 4$ & 2 & 1 & 1 & $\mathrm{~N}$ & 8 & Common & Training & $\begin{array}{l}\text { Continuous } \\
\text { monitoring }\end{array}$ \\
\hline
\end{tabular}

Table 1. Register of environmental aspects for the machining hall

\section{Conclusion}

The key part is the description of the draft register of environmental aspects in the field of machining, which be used as a basis for EMS documentation according to ISO 14001. Criteria were also used to calculate the significance of the identified environmental aspects of the machining process. The following criteria were chosen for this work: frequency of occurrence or duration of the impact, severity of the impact, the possibility of an accident, costs, and whether the activity is regulated by legislation. After calculating the significance assessment, it was found that important aspects during machining include the leakage of hazardous substances, the generation of waste from metallurgical material, the use of cutting oil in machining and the generation of waste oil. According to the created register, environmental objectives were selected for the identified significant aspects, for which possible corrective measures were written, which could help to reduce their significance.

The implementation of the environmental management system in the company can be divided into five stages of initiation, planning, implementation, control and evaluation. Opening, or preparatory stage in the framework for which the register of environmental aspects described above has been proposed. The planning stage will be the next step in which the revision of legislative requirements, the definition of environmental objectives (selection and planning of solutions to a very specific environmental problem), the elaboration of an environmental program (short-term, mediumterm and long-term measures to be implemented in order to achieve defined environmental objectives), setting the organizational and process structure (it is essential to establish responsibilities and powers in order to promote environmental policy objectives and programs). In the future, we also plan to perform an analysis of the implementation stage, which will include the achievement of the set goals according to the developed environmental programs. The task of the control phase will to implement such measurement and evaluation measures that ensure that the company's environmental management system operates in accordance with the established environmental management program and that areas corrective action are identified as soon as possible. Within the evaluation stage, the setting of the environmental management system in the company will be examined. An indicator will be used to evaluate the environmental profile and its changes according to ISO 14031.

Our research has confirmed that the company's impact on the environment can be great. Better use of resources, reduction of pollutant emissions, prevention of risks associated with environmental accidents and creation of safe working conditions is the goal of every company with an established environmental management system. Should however, to become not only the goal of every company, but also every employee of the company. Therefore, in the future we plan to design a plan for training the company's employees, the content of the training, including a number of practical workshops and a check of the professional competence of the employees.

\section{Acknowledgments}

This article was created under the project SGS-2019-008: Research and Development for Innovation in the Field of Manufacturing Technology - Machining Technology III. 


\section{References}

[1] Cascio, J., Woodside, G. \& Mitchell, P. (1996). ISO 14000 Guide, The New International Enviromental Standars. McGraw-Hill, New York, pp. 3-217

[2] Kralikova, R.; Pinosova, M.; Koblasa, F.; Wessely, E. \& Rusko, M. (2020). Environmental and Health Impact of Paint Products, Proceedings of the 31st DAAAM International Symposium, pp.0035-0043, B. Katalinic (Ed.), Published by DAAAM International, ISBN 978- 3-902734-29-7, ISSN 1726-9679, Vienna, Austria DOI: 10.2507/31st.daaam.proceedings.005

[3] Kudlacek, I. (2002). Industry ecology (in Czech), Prague ISBN 80-01-02495-4, Prague

[4] Veber, J. et al. (2010). Management of quality, environment and work safety: legislation, systems, methods, practice (in Czech), Prague ISBN 978-80-7261-210-9, Prague

[5] Sihag, N. et al. (2019). The Influence of Manufacturing Plant Site Selection on Environmental Impact of Machining Processes, Available from: https://1url.cz/OzYmQ

[6] Sobotova, L.; Badida, M. \& Wessely, E. (2020). Research of Laser Cleaning of Materials and Environmental Requirements, Proceedings of the 31st DAAAM International Symposium, pp.0176-0183, B. Katalinic (Ed.), Published by DAAAM International, ISBN 978-3-902734-29-7, ISSN 1726-9679, Vienna, Austria DOI: 10.2507/31st.daaam.proceedings.023

[7] Ojstersek, R.; Palcic, I. \& Buchmeister, B. (2020). Simulation Modelling of Environmental and Economic Aspects in Manufacturing Systems, Proceedings of the 31st DAAAM International Symposium, pp.0436-0443, B. Katalinic (Ed.), Published by DAAAM International, ISBN 978-3-902734- 29-7, ISSN 1726-9679, Vienna, Austria DOI: 10.2507/31st.daaam.proceedings.061

[8] HÄBERLE, G. et al. (2003). Environmental technology for school and practice (in Czech), Prague ISBN 80-8670605-2, Prague

[9] Blazevic, A.; Bibic, D.; Trobradovic, M.; Filipovic, I. \& Gebert, K. (2020). Effective Reduction of NOx Emissions of Modern Medium Speed Diesel Engines, Proceedings of the 31st DAAAM International Symposium, pp.08120818, B. Katalinic (Ed.), Published by DAAAM International, ISBN 978-3-902734-29-7, ISSN 1726-9679, Vienna, Austria DOI: 10.2507/31st.daaam.proceedings.113 